confusion; and in the second, although all parallel planes have the same slope, any number of other planes not parallel can also have it ; the word is therefore not sufficiently definite. "Tilt," a word spoken of by Mr. Proctor, as though it had been suggested, has no geometrical meaning whatever. As a substantive it is a " tent," or "awning ;" it has also been sometimes used poetically as an equivalent to "toumament," and is, I believe, the familiar aubreviation of "tilt-hammer." These are its only meanings, and none of them apply to a plane.

I would only add that I do not quite see what the fact mentioned by Mr. Proctor, that he has written twelve books in the last six years--interesting as it may be from a bibliographical point of view-has to do with the matter.

Oct. 29

J. K. LAUGHTON

THREL elements are necessary to fix the position of a plane as I understand the word "position." If "aspect" and "slope" be the names of two of these, the third will be the perpendicular upon the plane from some fixed point. It is because the term "position" implies the fixedness of this third element that it is inappropriate to express my friend Mr. Wilson's meaning.

My friend Mr. Proctor will pardon me if $I$ do not consider the question entirely settled by the fact that he has written perspicho'xsly and explained clearly by the use of a term which fixes too much. With an improved scientific terminology, he will be able to make his next twelve books superior (if that be possible) to those he has written within the last six years.

"Aspect" and "slope" stand on the same footing, one connotes a reference to the points of the compass, the other to the borizon. Neither can be used in Mr. Wilson's sense without departing from their colloquial meaning, but it is perfectly competent for geometers to take a word from common conversation and give it a scientific meaning. Either of these words may be used in Mr. Wilson's test sentences. Parallel planes have the same slope, two slopes determine a direction, \&c.

It is yet possible that some correspondent can suggest a better term, either one imported from ordinary life or one conceived for the purpose.

THE CORRESPONDENT WHO SUGgested "SlOPE"

\section{Geometry at the Universities}

Prof. Thiselton Dyer has well pointed out a distinction which exists between the mathematical courses at Oxford and Cambridge. But his conclusion, that at Oxford "special attention to geometrical methods would pay very well," though acceptable in its way, falls far short of what I advocate. The great want at both Universities is a course of geometrical studies; and the proof that such a want exists is to be found in the fact that the geometrical treatises in use at either University, cover so very limited a range. There are not even any text-books on the geometry of the sphere, cone, cylinder, and like simple solids, or on such curves as the lemniscate, cycloid, and the simpler spirals. A few stray notes on these subjects may be found in some of the text-books, but not a thorough and systematic geometrical investigation of any of them. Geometrical treatises might with advantage range much further. A geometrical treatise on ellipsoids would be of immense use apart from its employment as a means of mental training. Geometrical treatises on paraboloids of both kinds, on hyperboloids of one sheet and of two sheets, on the various orders of ring-surfaces and screw-surfaces, and on many other tiidimensional matters, would afford invaluable exercise to the student, besides having a real value to the scientific worker. I venture to express my conviction, that a course of such studies would tend to develop mathematical powers much more thoroughly even than the study of covariants and contravariants, Jacobians, Hessians, et hoc gemus omne.

If there is one department of mathematical research in which our countrymen are fitted by their mental habitudes todistinguish themselves pre-eminently, it is precisely this neglected department of geometrical research. As it is, though we have geometricians of great power, no systematic geometrical work is done in England. Our treatises sange only over the most elementary geometrical subjecte, and even in discussing these subjects our writers are fain to accept the assis ance of Continental geometricians. One would conceive that each of our Universities might yearly send out many who could treat of the elements of geometry without keeping a hand always on some French or German text-book.

Brighton, Oct. 27
DEEP-SEA DREDGING IN THE GULF OF ST. LAWRENCE

THE marine zoology of the deeper parts of the River and Gulf of the St. Lawrence has not been investigated until quite recently. This summer, under the auspices of the Natural History Society of Montreal, and in consequence of the kindness of the Hon. Peter Mitchell, Minister of Marine and Fisheries for the Dominion (who not only gave me facilities for dredging on board Govern. ment vessels, but also caused sufficient rope to be provided. for the purpose), depths of from 50 to 250 fathoms were successfully examined. The greatest depth in the Gulf, to the west of the Island of Newfoundland, as given in the Admiralty charts, is 3 I 3 fathoms. It is thought that a general sketch of the results obtained may be of interest to the readers of NATURE.

The cruise lasted five weeks, the first three of which were spent on board the Government schooner La Canadienne, and the remaining two on the Stella Maris. The area examined includes an entire circuit round the-Island of Anticosti, and extends from Point des Monts (on the north shore of the St. Lawrence) to a spot about half way between the east end of Anticosti and the Bird Rocks. As these investigations were almost necessarily subordinate to the special duties on which the schooners were engaged, in several cases the same ground was gone over twice.

The bottom at great depths generally consists of a tough clayey mud, the surface of which is occasionally dotted with large stones. So far as I could judge, using an ordinary thermometer, the average temperature of this mud was about $37^{\circ}$ to $38^{\circ}$ Fahrenheit, at least on the north shore. In the deepest parts of the river, on the south shore, between Anticosti and part of the Gaspe Peninsula, the thermometer registered a few degrees higher. Sand dredged on the north shore in 25 fathoms also made the mercury sink to $37^{\circ}$ or $38^{\circ}$.

Many interesting Foraminifera and Sponges were obtained, but as yet only a few of these have been examined with any care. A number of Pennatulæe were dredged south of Anticosti ; the genus has not been previously recorded, so far as I am aware, as inhabiting the Atlantic coast of America. They were found in mud, at depths of 160 and 200 fathoms, and it seems probable that this species, at least, is sedentary, and that it lives with a portion of the base of the stem rooted in the soft mud. $A C$ timia dianthus and Tealia crassicornis were frequent in 200 to 250 fathoms. The Echinoderms characteristic of the greater depths are a Spatang us (specifically distinct from the common British species), Ctenodiscus crispatus, Ophioglypha Sarsii (very large), Ophiacantha spinulosa, and Amphiura Holbollii. Marine worms, of many genera and species, were both numerous and fine. Among the more interesting of the Crustacea were $N y$ mphon grossipes (?) and a species of Pycnogonum. Several of the last named Crustaceans were taken at a depth of 250 fathoms, entangled on a swab, fastened in front of a deep-sea lead, which was attached to the rope, a few feet from the mouth of the dredge. This circumstance tends to show that the genus is not always parasitic in its habits. The Decapods, Amphipods, \&c., at least those of greatest interest, have not yet been identified. Among the most noticeable of the marine Polyzoa are Defrancia truncata, and what appears to be a Retepora. Not many species in this group were obtained in very deep water, and those procured were, for the most part, of small size. About six species of Tunicates were collected. Being anxious to have Mr. J. Gwyn. Jeffreys' opinion upon the various species of Mollusca during his visit to Montreal, I studied these carefully first, and submitted the whole of them to him for examination. Twenty-four species of Testaceous Mollusca were obtained at depths of from 90 to 250 fathoms. Nearly all of these are Arctic forms, and eleven of them are new to the continent of America.

The following are some of the most interesting of 